\title{
FROM THE IDEA OF AN INNOVATIVE PERSON BY MR. JOSEPH ALOIS SCHUMPETER TO A CONCEPT OF INNOVATIVE DEVELOPMENT OF SOCIOECONOMIC SYSTEMS
}

\author{
YURI PERSKY, JULIA DUBROVSKAYA
}

\author{
Perm National Research Polytechnic University, Russia
}

\begin{abstract}
The article attempts to extrapolate the innovative key ideas of Joseph Alois Schumpeter for more complex multi-level socioeconomic systems. A hypothesis of a hierarchical approach to the research study of the innovation development is introduced, which explains that an "interlevel interaction" contains an extensive effective potential represented as synergy effects of different kinds which are reflecting one of the major well-known properties of any system - emergence property. Based on an econometric modelling of cross-country indicators, a hypothesis confirmation is provided on an example of the local government system as a factor of harmonizing the economic entities interests at different hierarchical levels.
\end{abstract}

\section{JEL CLASSIFICATION \& KEYWORDS}

- C50 - O11 - Innovative development - Inter-level interaction a System of local government a Institutions

\section{INTRODUCTION}

In scientific literature and mass media the issues related to the possibilities of countries transition to a new and innovative way of development are being increasingly more often discussed. In this regard, an innovation in the wide meaning of this word is usually regarded as an innovation providing a quality growth of efficiency of the already existing system.

Joseph Alois Schumpeter put an innovator-entrepreneur who was "a driving force behind the re-organization of economic life" (1982) into the centre of cyclical economic development, and it made certainly an undeniable contribution to the economic science. The present study attempts to extrapolate the innovative key ideas of Joseph Alois Schumpeter for more complex multi-level socioeconomic systems, which are characterized by the multiple needs of interest groups while there is a continuous process of interaction. According to this, a hypothesis is made that the effects of inter-level interaction have signs of innovation, since any changes (innovations) of a progressive kind objectively become development factors. Based on an econometric modelling of cross-country indicators, a hypothesis confirmation is provided on an example of the local government system as a factor of harmonizing the economic entities interests at different hierarchical levels.

\section{An innovative economics analysis by Joseph Alois Schumpeter}

It is known that any innovations in the market economy are effective competitive tools due to the forming of new requirements; they contribute as well to additional investments, improve the image of a new products manufacturer, open and enter new markets. It is innovation that is the factor of decision-making of creating competitive products which have a high level of research intensity and innovation.

The fundamental classical contribution to the economic science and practice was made by Joseph Alois Schumpeter who focused on the recognition of the dominant role of innovations in development. The foundation of his innovative economics analysis is based on the factors that "blow up" the balance of the market system from inside - new www.journals.cz/ production combinations determining the dynamic changes in the economy. Considering the innovation management at the micro level, it is detailed elaboration of task of managing competitiveness of a company based on the innovative element which might be represented by any models of the innovative process. In this regard, the following five constructive approaches developed by the British economist Roy Rothwell (1992) can be qualified as sufficient for the model building of an innovative process [1]:

1. First generation (1G) - technology - push mode. This approach is related to the appearance of an idea of creating a new product within the structures of $R \& D$, while the market plays a passive role, only accepting the results of research and development.

2. Second generation (2G) - market pull model. The market plays more significant role. It is assumed that innovation occurs as a result of some discovered needs of consumers that indicates a lack of clearly defined research and development leading to the emergence of new products on the market on demand of the market.

3. Third generation (3G) - coupling model (a combined approach $1 G+2 G$ ). With this approach the role of the market, marketing and technical factors increases significantly, partly reflecting a nonlinear link between them.

4. Fourth generation (4G) - integrated model (an intergraded view). This approach marked a clear transition from a primarily sequential innovation process to a parallel process, i.e. essentially to a marked labour division at each stage and to a closer connection between production and research (computer-aided design, flexible system). The feature of this model is to create multi-functional working teams (engineers, designers, marketing experts, economists), which provide a very effective free flow of knowledge (ideas, knowledge, experience, etc.).

5. Fifth generation (5G) - sin model (system integration and networking - model of strategic networks). This approach defines the innovative process not only as a multifunctional one but also a multi-institutional process. It means the social process which gets together any agents inside and outside the organization, i.e. a developed network process (a cluster). For this approach not as much the competition as the good relationship within a co-operation is important which represents the fundamental characteristics of postindustrial economics in its newest form.

A practical application of either approach depends on the nature of company's strategy, on influence of macroeconomic parameters and on specific company situations in the market. The above introduced approaches significantly enrich and develop the key ideas of Joseph Alois Schumpeter in the innovation development as they reflect positive evolutionary dynamics of innovation processes in the context of global trends, namely the development of forms and interaction modes of the market, organizational, technological and institutional mechanisms for the creation of innovation. 
These innovative-competitive bases of development devised by Joseph Alois Schumpeter have concerned first of all social and economic systems of micro level, basic components (subsystems) of which are a person, a process, a product and a firm. It is natural, as the economic science has arisen and also developed in conditions of prevalence of the microeconomic analysis for a long time. Today it is possible to say, that Joseph Alois Schumpeter's innovative heritage is applicable to any social and economic system of various levels of hierarchical economy.

\section{The hierarchical approach to research of innovative processes}

Functioning of economy composes processes of creation, interaction and transformation of economic systems of various levels. The economic system includes not only interrelations between elements of one of levels of economy, but also interrelation and interdependence between objects of various levels. In this connection the problem of research of innovative processes in view of interconditionality and interferences of activity of economic subjects of various levels of economic system (territorial systems and subsystems, commodity-producing systems - not only the enterprises-firms, but also branches, complexes, clusters, the branch markets, functional subsystems, etc.) objectively becomes actual. Thus, the listed systems as more complex concerning the enterprise, are considered multilevel hierarchical systems as poly-hierarchical systems. In the given context the economic system is understood not in purely terminological meaning, as a final set of functional elements and connection between them, allocated of the environment with a definite purpose, but in multivariate vision - as poly-structural system (Figure 1).

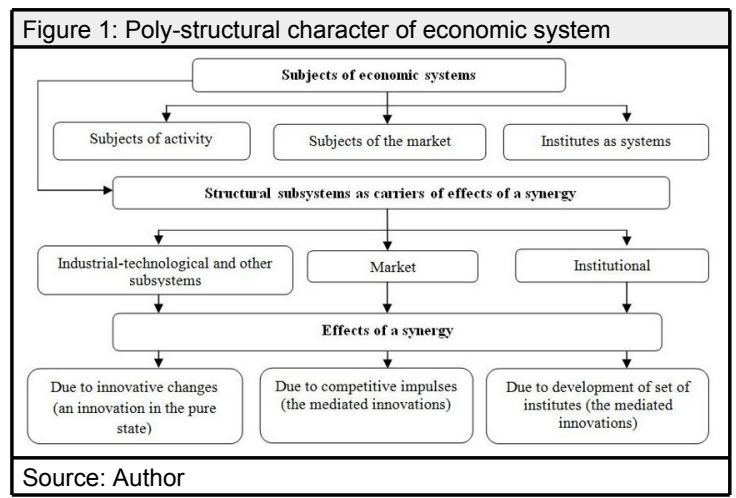

According to figure 1 economic system is not only a set of subjects, but also a set of the structural subsystems playing a role of carriers of effects of a synergy. As the basic characteristic of hierarchical (interlevel) approach to the analysis of economy is a deep representation of economy as a complex system consisting of a set of elements and connections between them, it is important to notice, that the system making integrity, consists of elements, which behave as integrity as well. In this connection, the object of research of interlevel analysis in economy is vertical and horizontal interrelations between various levels of hierarchical system and their influence on properties of the whole system. Thus, interlevel interaction modifies a traditional approach to the description of elements of economic system: from the point of the system approach the place of each element in a system, its role, functions, influence are analyzed; from the point of the hierarchical approach any object of economy is considered in the frame of hierarchical connections, its influences on elements of different levels. Thus, the interlevel interaction generates effects of a synergy, the structure and maintenance of which represent an independent subject of the theoretic-applied analysis of hierarchies.

\section{Hypothesis of the hierarchical approach to research of innovative development of complex social and economic systems}

"Interlevel interaction" comprises rich potential of efficiency on behalf of effects of a synergy of the various character, reflecting one of the basic well-known properties of any system - emergence property, which is expressed in a complex of effects of a synergy (effects of interlevel interactions) which have innovative features, as any changes (innovation) of progressive character objectively become factors of development. The given hypothesis is represented especially significant for consideration of a problem of harmonization of interests of subjects of economy of various levels from the position of a hierarchical approach.

Development of the effective control system containing potential of innovative development demands the analysis and the estimation of quality of the institutes, organizing functioning of economic subjects and definitions on the given basis of a vector of administrative influences at various levels of hierarchy. In the given context questions of harmonization of interests of economic subjects in the system of hierarchical interrelations of economy demand special attention. Consideration of the institutional problematics of the given subject of scientific research is exclusively needed for the processes of hierarchical interaction in the system of the state and territorial management and regulation.

The fact that harmonization of interests of various subjects of economy is an important component of steady development of national social and economic system does not cause any disputes among economists. At the same time, the analysis of references has shown, that existing theoretical and applied researches consider the process of harmonization of interests, basically, in view of separate levels of economic system, owing to the thing that the problem of harmonization of interests in economy as in a complete hierarchical system, remains insufficiently explored and demands further studies.

Thus, in conditions of innovative economy of one of the most significant problems of the state policy there is determination of adequate effective directions of integration and harmonization of interests of various subjects of national economic system. Being based on the fact that in the hierarchical analysis division of the economic system into levels according to a definite attribute is primary, the hierarchical structure of economic system on the basis of their interests can be presented as follows (Table 1).

In the considered context the harmonious economy is understood as the economic system in which conditions for complex development of all levels of hierarchy on the basis of a combination of interests of the given levels subjects are created.

According to the conventional system and the hierarchical approach, quality of functioning of the economic system is provided with a feedback appearing during interaction of subjects of economy of various hierarchical levels. Therefore the primary goals of achievement of harmonious economy are search of ways and institutes of interaction of economy subjects and an estimation of efficiency of such institutes functioning. To provide a feedback between the state and the individual is the role of civil society which consists of various formal and informal public associations, contributing 


\begin{tabular}{|l|l|l|l|l|}
\hline \multicolumn{3}{|l|}{ Table 1: A hierarchical structure of economic system on the basis of interests of subjects of economy of various levels } \\
\hline Level of hierarchy & Objects of a level & Subjects of a level & Interests & The purposes of realization of the interest \\
\hline Mega-economy & $\begin{array}{l}\text { Macro-economic } \\
\text { systems of all } \\
\text { countries }\end{array}$ & $\begin{array}{l}\text { Institutions of the state } \\
\text { regulations of the } \\
\text { highest level of } \\
\text { authority }\end{array}$ & $\begin{array}{l}\text { International } \\
\text { interests }\end{array}$ & $\begin{array}{l}\text { Guarantee of equal participation in world } \\
\text { economic relations, control of dependence on } \\
\text { business environment of the international } \\
\text { tradable and resource markets }\end{array}$ \\
\hline Macro-economy & The state & $\begin{array}{l}\text { Federal State } \\
\text { governmental authority }\end{array}$ & National interests & $\begin{array}{l}\text { Growth of the national income, social welfare, } \\
\text { rate of economic growth }\end{array}$ \\
\hline Meso-economy & $\begin{array}{l}\text { Municipal } \\
\text { formations }\end{array}$ & $\begin{array}{l}\text { Institutions of the } \\
\text { region and local } \\
\text { government }\end{array}$ & Municipal interests & $\begin{array}{l}\text { Improvement of a standard of living of the } \\
\text { population of the territory on the basis of increase } \\
\text { of its competitiveness and steady development }\end{array}$ \\
\hline Micro-economy & $\begin{array}{l}\text { The enterprises, } \\
\text { households }\end{array}$ & $\begin{array}{l}\text { Heads of the } \\
\text { enterprises, household } \\
\text { heads }\end{array}$ & $\begin{array}{l}\text { Private interests } \\
\text { (own results) }\end{array}$ & $\begin{array}{l}\text { Increase in a share of the market, maximization } \\
\text { of profit. Growth of consumer opportunities, } \\
\text { utility maximization }\end{array}$ \\
\hline Nano-economy & Set of individuals & Individuals & $\begin{array}{l}\text { Individual } \\
\text { (personal) interests }\end{array}$ & $\begin{array}{l}\text { Satisfaction of material, spiritual, social, etc. } \\
\text { needs }\end{array}$ \\
\hline Source: Author & \multicolumn{3}{|l}{} \\
\hline
\end{tabular}

to development of public sphere and allowing citizens to realize their interests and initiatives by influence on bodies of public authority. For definition of conditions of formation and development of democratic institutes, authors have developed the functional matrix of economic subjects of various hierarchical levels (table 2). The matrix is constructed on the basis of the standard classification of functionalities of the basic sectors of a democratic society: public sector (imperious function), economic sector (economic function) and social sector (function of selforganizing of citizens).

\begin{tabular}{|l|l|l|l|}
\hline $\begin{array}{l}\text { Table 2: A functional matrix of economic subjects of various } \\
\text { hierarchical levels }\end{array}$ \\
\hline \multirow{2}{*}{ Economic subjects } & $\begin{array}{l}\text { Functions of the basic sectors of a } \\
\text { democratic society }\end{array}$ \\
\cline { 2 - 4 } & $\begin{array}{l}\text { Imperious } \\
\text { function }\end{array}$ & $\begin{array}{l}\text { Economic } \\
\text { function }\end{array}$ & $\begin{array}{l}\text { Function of self- } \\
\text { organizing of } \\
\text { citizens }\end{array}$ \\
\hline $\begin{array}{l}\text { Institutions of state } \\
\text { government }\end{array}$ & + & + & - \\
\hline $\begin{array}{l}\text { Institutions of local } \\
\text { government }\end{array}$ & + & + & + \\
\hline $\begin{array}{l}\text { Subjects of a micro- } \\
\text { level including }\end{array}$ & & & \\
\hline $\begin{array}{l}\text { - noncommercial } \\
\text { organizations }\end{array}$ & - & + & + \\
\hline $\begin{array}{l}\text { - commercial } \\
\text { organizations }\end{array}$ & - & + & - \\
\hline - households & - & + & - \\
\hline Source: Author & & \\
\hline
\end{tabular}

As it follows from table 2 subjects of local government (municipal formations) have all functions. The municipal level takes intermediate position between bodies of the government and the structures representing the population (the enterprises, households); it also has steady interrelations with both. Only at the municipal level it is possible to involve the population in the procedure of definition of priorities of social and economic development of the territory and development of a civil society.

In the present research municipal formation is considered as relatively autonomous territory of habitation of people with common needs caused by functioning of local authorities (municipal community) within the limits of which work of local government is carried out. But as the basic feature of local government is by-law local authorities (strengthening of legal basis of activity of local selfmanagement by the government), despite the autonomy of local government consolidated by the legislation in relation to the state, municipal authorities are called to continue the policy of the central local authorities. Thus, objectively acting in the status most the level of public authority closer to the population, institutions of local government have a unique opportunity to realize the state policy in interests of local communities according to institutional features of certain municipal formations. In such context local government is the mechanism of purposeful interaction of municipal communities and the states, solving the problem of the coordination of relevant interests.

The above-stated causes necessity of the further research of functioning of a system of local government and the institutes defining conditions of functioning of the given system as opportunities of harmonization of subjects interests of economy of various levels and as the factor of innovative development.

The solution of the stated problem assumes getting of the system characteristic of influence of the developed institutional environment on the processes of harmonization of interests and on the given basis finding out the reasons of inefficiency of the institutes absolutely influencing the process of interaction of subjects of economy as hierarchical system with its complex inter-level interrelations on the basis of management innovations.

During the analysis institutes of local self-management have been aggregated into three groups: institutes of support of the local self-management with norms (laws) defining the place and the role of local government in the system of public institutes of the country; institutes of information and interaction representing norms, formed during communicational relations of institutions of local government with subjects of economy; the value-mental institutes of local government which are being informal institutes having value-mental features of municipal community and legal culture. Such synthetic aggregation of institutes objectively predetermines innovative character of their influence on processes of harmonization of interests by virtue of innovative interaction of subjects of interest bearers.

In a view of the aforementioned the hypothesis about significant influence of generated institutional structure of local government on intensity of inter-level interactions, capable to provide harmonization of interests of economic subjects has been put forward. According to the given hypothesis institutional environment of a municipal level of economic hierarchy contains significant potential of interlevel interaction, realization of which is capable to make an active process of harmonization of interests of economic subjects of various hierarchical levels. Therefore there is a necessity of revealing the areas of institutes dysfunctions, organizing functioning of system of local government with 
the purpose of definition of the basic directions of the administrative influences, capable to provide favorable conditions for its development.

Doing the given task demands definition of criteria of institutional structure efficiency. The criterion estimation of efficiency of institutes assumes making the system characteristic of influence of the developed institutional environment on processes of harmonization of interests and finding out on the given basis the reasons of an inefficiency of institutes of local government which as it has been shown have significant influence on process of interaction of economy subjects as a hierarchical system with its complex inter-level interrelations. In this connection there is an independent problem of the specification of the carried out research in wide and narrow aspects. The most effective decision can be received with use of the tool of econometric modeling.

\section{Econometric modeling of harmonization process of interests of economy subjects}

In wide aspect the specification of research is developed on the assumption that poor quality of institutional environments as a whole interferes with harmonization of interests of economic subjects of various hierarchical levels that finally finds reflection in a low standard of well-being. For definition of dependence of harmonization process of interests on set of institutes we adhered to a method of inter-countries comparisons, using as the indicator of efficiency of institutional environment a Composite Index of Economic Freedom [The Fraser Institute, The Annual Report: Economic Freedom of the World, 2007].

The explained variable that describes a level of harmonization of interests of various subjects of economic hierarchy Human Development Index (further - HDI) has been chosen, representing an average arithmetic indices of average life expectancy, education and GDP [United Nations Development Programme, the Human Development Report, 2007]. Choice of HDI as a parameter of a level of harmonization of interests of economic subjects means that an ultimate goal and the highest interest of activity of economic subjects of various hierarchical levels is well-being of people. In this case we proceeded from the fact that harmony of interests is characterized by unity of the purposes of all elements of a system and a single orientation of their actions. For an estimation of the role of institutional inefficiency during harmonization of interests, dependence of HDI on five components was analyzed, which all together compose the Index of Economic Freedom. As a result of the construction of the multi-factorial econometric model significant functional connection has been received:

$$
\begin{aligned}
& H D I=0,059+0,008^{*} X 1+0,069^{*} X 2+0,016^{*} X 3+0,041 * X 4-0,026^{*} X 5 \\
& (1,29) \quad(9,20) \quad(1,72) \quad(3,91)
\end{aligned}
$$

quality of the model $\left(R^{2}\right)-69 \%{ }^{2}$

X1 - Size of Government: Expenditures, Taxes, and Enterprises; X2 - Legal Structure and Security of Property Rights; X3 - Access to Sound Money; X4 - Freedom to Trade Internationally; X5 - Regulation of Credit, Labor, and Business.

According to the received formula, the greatest influence on the chosen function has the parameter X2 - index Legal Structure and Security of Property Rights (further LS\&SPR), a characterizing level of legal stability and a civil society in the country. The given fact testifies that a level of development of democratic institutes in the country renders much greater influence on an index of human development, than a level of development of such institutes as free trade, the monetary market, public sector, etc.

Being based on the received results, we used further specification of econometric models in a narrow aspect. This model was being formed on the idea that formation of a high-grade civil society can be made effectively active at a municipal level of economic hierarchy during development of institutes of local government.

In this connection there was a necessity for the additional analysis of institutional inefficiency of the local government system, carried out on the basis of usage of methods of correlation and the regression analysis. For an estimation of the role of the institutional inefficiency of the system of local government in Russia, dependence of LS\&SPR on quality of the institutes defining conditions of functioning of system of local self-management (further - LSM) has been consistently analyzed. Results of modeling LS\&SPR are presented in table 3 .

\section{Conclusion}

In the article the problem of research of innovative processes with consideration for inter-dependence and interaction of activity of economic subjects of various levels is made actual on the basis of representation of economic

\begin{tabular}{|c|c|c|c|}
\hline Institutes of LSM & Explaining parameters & The formula of regress & Evidence of institutional failure \\
\hline $\begin{array}{l}\text { Institutes of } \\
\text { support }\end{array}$ & $\begin{array}{l}\text { SC (Social charges of the state) - the level of cumulative } \\
\text { social expenditures of the consolidated budget of the country } \\
\text { (branches: healthcare, education) in percentage of GNP of } \\
\text { the country. } \\
\text { The biggest percentage of expenditure of municipal budgets } \\
\text { is given to education and healthcare. At the same time, } \\
\text { quality of municipal services in these spheres directly } \\
\text { depends on their resource provision regulated by } \\
\text { government authorities. governmental authorities. }\end{array}$ & $\begin{array}{l}\text { LS\&SPR }=2,34+0,47^{*} S C \\
\text { quality of the model } \\
\left(R^{2}\right)-63 \%\end{array}$ & $\begin{array}{l}\text { Inefficient policy of the state in } \\
\text { the field of resource provision } \\
\text { of the obligation assigned to } \\
\text { municipal authority that } \\
\text { discredits local authorities in } \\
\text { eyes of the population. }\end{array}$ \\
\hline $\begin{array}{l}\text { Institutes of } \\
\text { information and } \\
\text { interaction }\end{array}$ & $\begin{array}{l}\text { FP - Freedom of the Press World Ranking. } \\
\text { IU - Internet users. } \\
\text { As a whole, the arguments chosen for the analysis represent } \\
\text { the indicator of information freedom in municipal community. }\end{array}$ & $\begin{array}{l}\text { LS\&SPR }=4,16+ \\
0,017^{*} \mathrm{FP}+0,034^{*} \mathrm{IU} \\
\text { quality of the model } \\
\left(R^{2}\right)-72 \%\end{array}$ & $\begin{array}{l}\text { Undeveloped system of forms } \\
\text { of interaction (including an } \\
\text { information component) of local } \\
\text { authorities and economic } \\
\text { subjects. }\end{array}$ \\
\hline $\begin{array}{l}\text { Valuable and } \\
\text { mental institutes }\end{array}$ & $\begin{array}{l}\text { TInt -Trust interpersonal; } \\
\text { Tins - Trust to institutes. } \\
\text { These are the major components of a parameter of social } \\
\text { capital of the local government (the inhabitants of municipal } \\
\text { formation focused on support of LSM and realizing the right } \\
\text { for the solution of problems of local value). }\end{array}$ & $\begin{array}{l}\text { LS\&SPR }=4,22+ \\
0,044^{*} \text { TInt }+0,024^{*} \text { TIns } \\
\text { quality of the model } \\
\left(R^{2}\right)-65 \%\end{array}$ & $\begin{array}{l}\text { Formed conformism, } \\
\text { dispassionateness of the } \\
\text { population; "a society of } \\
\text { mistrust" interfering with } \\
\text { interaction of authorities and } \\
\text { population. }\end{array}$ \\
\hline
\end{tabular}
system as a poly-structural system. It has allowed making 
the supposition that "inter-level interaction" contains potential of efficiency on behalf of effects of a synergy as any innovations of progressive character objectively become factors of development.

The empirical proof of the supposition has been carried out within the limits of consideration of the problem of harmonization of interests of economic subjects in the system of hierarchical interrelations of economy. On the basis of the offered hierarchical structure of economic system on grounds of interests of subjects of economy of various levels, and also the constructed functional matrix of subjects of management by economy, it has been revealed that the significant potential of the inter-level interactions, realization of which is capable to make active process of harmonization of interests of economic subjects of various hierarchical levels is at a municipal level of economy.

Modeling of institutes of local government has revealed presence of direct, close connection with a level of development of a civil society as the most significant factor of harmonization of interests of economic subjects in conditions of innovative development of economy.

Results of the carried out econometric analysis confirm necessity of application of the inter-level approach to research of innovative development of complex social and economic systems. On this basis there is an opportunity to develop efficient mechanisms of innovative management by means of development of complex social and economic systems, which confirms solitariness and inexhaustibility of influence of the creative innovative work of Joseph Alois Schumpeter on the theory and practice of economy.

\section{REFERENCES}

1. Rothwell, Roy. "Successful Industrial Innovation: Critical Factors for the 1990s." R\&D Management, 22.3 (1992): 221-239.

2. Schumpeter, Joseph Alois. The theory of economic development (Research of enterprise profit, the capital, the credit, percent and a cycle of a conjuncture). Moscow: Progress, 1982.

3. The Annual Reports: Economic Freedom of the World. 1970 -2009. Vancouver. The Fraser Institute. 15 Nov. 2009. $<$ http://www.freetheworld.com/release.html>.

4. The Human Development Reports. 1990-2009. New York. United Nations Development Programme. 15 Oct. 2009. <http://www.undp. org/content/undp/en/home/librarypage/hdr.html>. 